\title{
EFFECT OF ELEVATED COOLANT TEMPERATURE ON THE EXHAUST COMPOSITION OF PISTON INTERNAL-COMBUSTION ENGINE
}

\author{
Rafał Krakowski \\ Faculty of Marine Engineering \\ Morska Street 83, 81-225 Gdynia, Poland \\ tel.: +48586901398 \\ e-mail:r.krakowski@am.gdynia.pl
}

\begin{abstract}
There is a tendency to increase the economic efficiency of engine operation and energy efficiency and reduce emissions of toxic combustion products. One way to reduce emissions of toxic components in exhaust gases is raising the coolant boiling point, which requires the simultaneous increase in pressure in the cooling system. Previous studies suggest that such a system can reduce the amount of toxic components in exhaust gases, particularly at low engine load when the engine exhaust temperature is too low to make effective catalytic action. The paper presents the model and experimental test stands to research the cooling system at an elevated temperature of the coolant. The speed and load characteristics of the standard cooling systems and pressure were presented. The research results were designed to determine the effect of elevated temperature in the cooling system on the composition of the gases. The characteristics of the external speed and load were performed with standard cooling systems and pressure. When performing velocity characteristics of the engine was loaded up in the whole range of engine speed from 1000 to 4000 rev/min, while the load characteristics were performed for different values of torque at constant speed in the range from 1500-4000 rpm. The results confirmed the benefits of increasing the temperature of the coolant. The presented characteristics that apply pressure cooling system reduces the amount of toxic components in exhaust gases, particularly at low engine load, in which the engine operates most often in urban conditions.
\end{abstract}

Keywords: combustion engines, engine cooling, exhaust emissions, air pollution, environmental protection

\section{Introduction}

Piston internal combustion engines are still widely used for vehicle propulsion, and work on their development is also carried out to reduce toxic emissions. In piston engines, the most popular and widely used method of cooling is a cooling liquid, which provides a more uniform temperature distribution around the combustion chamber, and therefore water-cooled engines are still under research and development $[6,8]$.

One source of this energy loss is the need for engine cooling. Water, commonly used to cool the engines is characterized on the one hand by large heat capacity and good heat transfer and on the other hand has a relatively low boiling point compared to the temperature those results from the properties of structural materials and lubricants, which forces the liquid to maintain the temperature below boiling point of water. To increase the boiling point of water is necessary to increase the pressure in the cooling system, which can be obtained by allowing for partial evaporation of water $[1,10]$.

Currently produced vehicles with both spark ignition engines and the diesel engines must fulfil the increasingly stringent requirements for environmental protection. Economic condition of the piston engine operation and the emissions of toxic compounds is the effective use of heat energy during combustion in a separate engine cylinders. Efficiency of liquid cooling systems, as assemblies in a complex system of energy management in vehicles, can be increased by the use of electronic control units of these systems work [2-4].

Research of the cooling system indicates that the amount of toxic components in exhaust gases can be reduced at low engine load when the exhaust temperature of a classical system is too low for effective catalytic action $[5,11]$. 


\section{Measurements of exhaust components}

To analyze the composition of exhaust gas analyzers, set to measure of shares of exhaust gas components was used. These analyzers were installed in the measuring cabin and were connected with heated sample gas distribution system. The exhaust gases flowing from the cylinder drove air compressor turbine, and then flowed by oxidising catalytic converter into the chimney dyno. In a straight section behind the turbine, outlet pipe placed sampling sensor into the composition analysis CEB-II and the AVL-486 opacimeter. The exhaust gases to analyze their composition were taken by a sensor across the pipe outlet. The sensor was connected to short section of heated gas path from the initial filter, where the long way exhaust gas flowed to the exhaust gas analyzers.

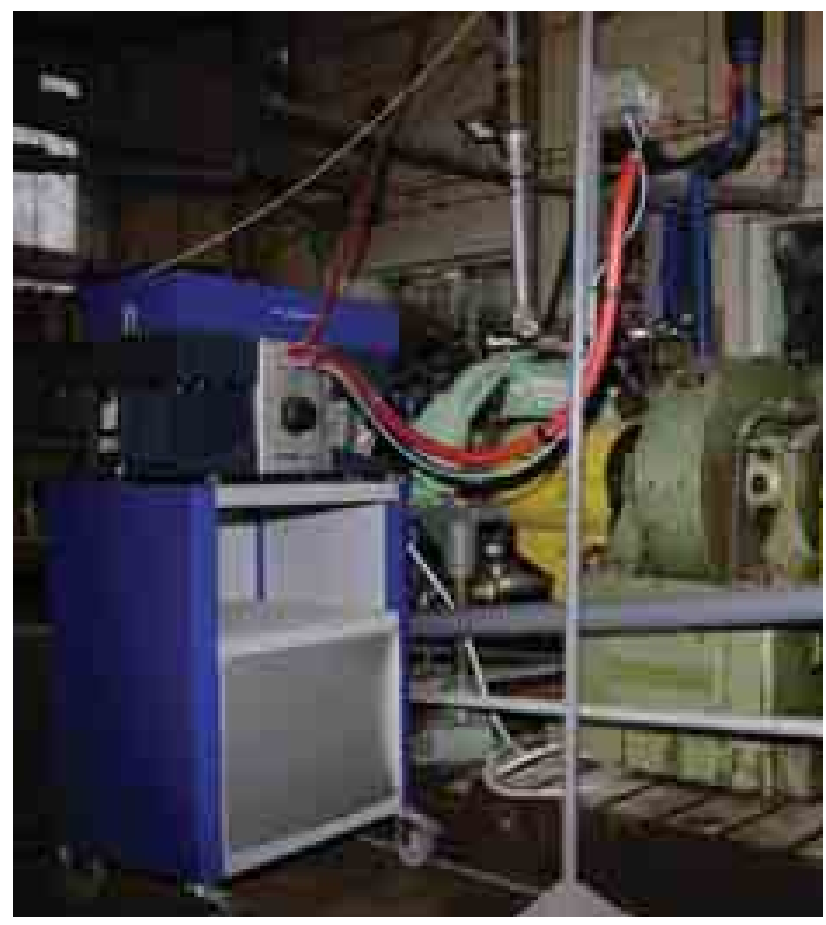

Fig. 1. Measurement of smoke opacity by means the opacimeter AVL-486

Smoke opacity was measured by means the opacimeter AVL-486 operating on the principle of light absorption along the reference section of gas pipe inside the opacimeter (Fig. 1). Measurements took place while maintaining adequate gas density, obtained by conditioning of the exhaust fumes inside the smoke pipe. Shares of selected components exhaust gases were measured using a fully automated, computer-controlled system CEB II manufactured by AVL. The exhaust gases were taken by sensor placed across in the straight section of the outlet pipe and then purified in the pre-filter. Then they flowed to the gas metering assembly to the different analyzers.

For analyzers that require hot exhaust gas (about $195^{\circ} \mathrm{C}$ ) the flow was taken directly from the heated gas path. Water vapour was outdropped from exhaust gas in the cooler, directed to the cold exhaust gas analyzers. Furthermore, compressed and thoroughly cleaned air and hydrogen were fed to the analyzer and the exhaust gases flowing from the analyzer were directed to the statement.

Shares of nitrogen oxides NO and NOx were measured using a chemiluminescent detector analyzer vacuum EcoPhysics company. $\mathrm{CO}$ and $\mathrm{CO}_{2}$ analyzers operate on the principle of absorption of infrared radiation, and the principle hydrocarbon analysis was based on the combustion of hydrocarbons (radial-Ionization). These analyzers were from Hartmann-Braun. All analyzers were built into the cabinet of gas sample conditioning system. Calibration gases were supplied to analyzers, two concentrations of each of the measured exhaust emissions. Gas tanks were placed in the rack and using teflon hose was connected to the fixed network, the feed gas to the analyzers. Hydrogen tank was located in a separate room, outside the dynamometer. 


\section{The research object}

The research object was turbocharged diesel engine 4CT90 680/59 production of "ANDORIA" SA. It is a four-cylinder engine with indirect injection into the vortex chamber (COMET RICARDO VB) performed in the cylinder head. 4CT90 engines are designed to drive vehicles with a total weight of 4.5 tonnes, and can be used as a source drive off-road vehicles, power generators and other stationary equipment. View of the engine on the dynamometer is shown in Fig. 2.

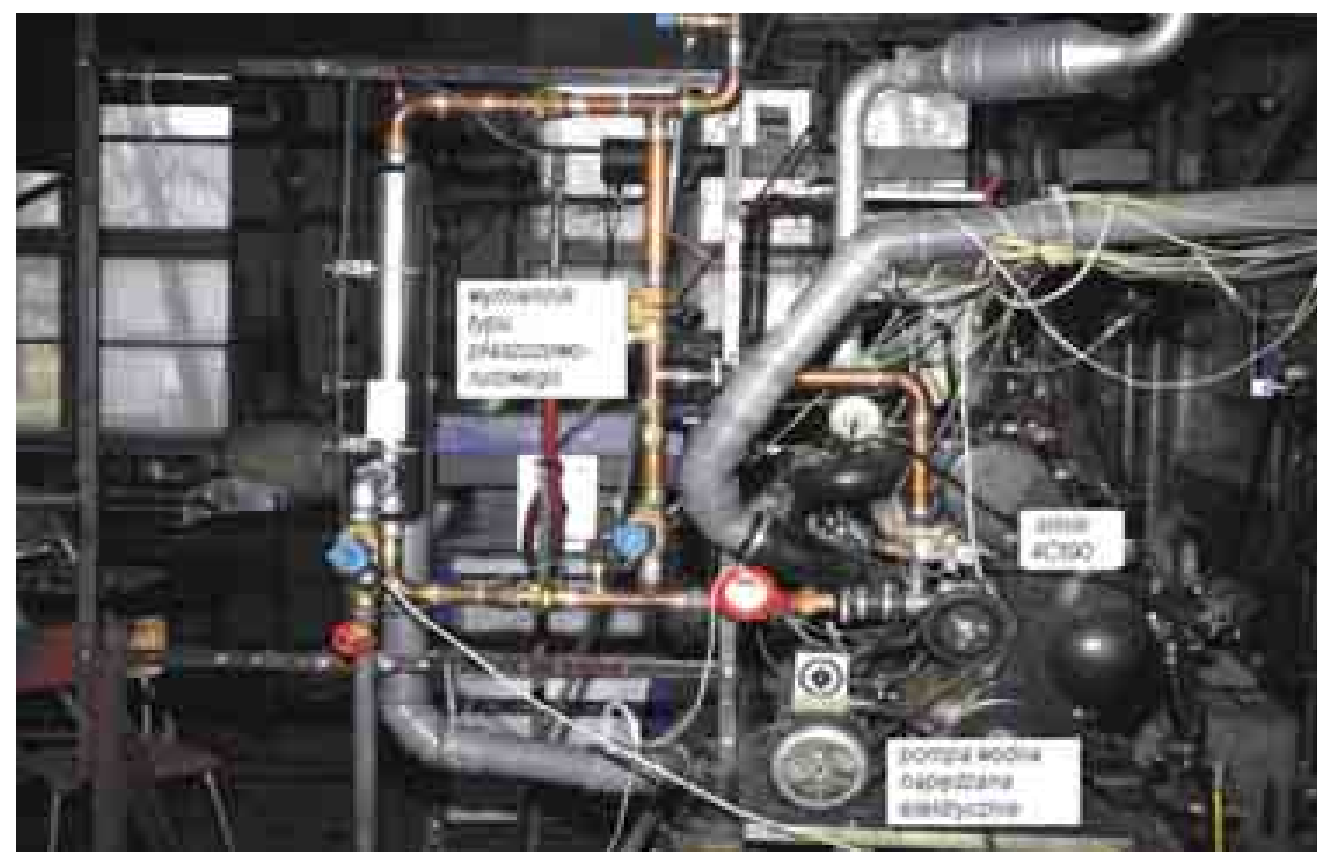

Fig. 2. Engine 4CT90 on the dynamometer with cooling system pressure

\section{The engine speed and load characteristics}

These studies were designed to determine the effect of elevated temperature in the cooling system on the engine useful parameters, exhaust gas composition and the effect of engine speed on the engine temperature. External speed characteristics were performed with standard and pressure cooling systems. While performing characteristics the engine was loaded up in the whole range of engine speed from 1000 to $4000 \mathrm{rev} / \mathrm{min}$.

These studies were designed to determine the effect of elevated temperature in the cooling system on the engine useful parameters, engine exhaust gas composition and the effect of load on the engine temperature. Load characteristics also performed with the standard and pressure cooling systems.

The research was conducted for different values of torque at constant speed in the range from 1500 to $4000 \mathrm{rev} / \mathrm{min}$. In this article the characteristics of the speed $\mathrm{n}=2500 \mathrm{rev} / \mathrm{min}$, at which the engine develops maximum torque, was presented.

\subsection{Effect of elevated coolant temperature on the exhaust composition}

The increased temperature of the coolant makes far greater share of nitrogen oxides in the whole speed range. In comparison to the standard cooling system, it is an increase of 50-100 ppm (Fig. 3a) at the speed ranges $1500-4000 \mathrm{rev} / \mathrm{min}$. In relation to the shares measured for the engine with a standard cooling system is increased on average about $15-30 \%$, with relatively low shares of nitrogen oxides in the engine tested with divided combustion chamber. Due to the 
combustion system, the shares of nitrogen oxides in exhaust gases are much lower in comparison with engines that have unshared the combustion chamber. However, a relative, a large increase in the share of nitrogen oxides can be justified by the increased air-filled motors (higher concentration of oxygen and higher combustion temperatures). The engine worked-off exhaust gas recirculation, and exhaust system was not equipped with catalytic reducing nitrogen oxides. The use of this reactor will be necessary in the engines cooling systems for temperature-elevated coolant.

Shares of oxygen in the exhaust of the engine with a pressure cooling system are comparable to the shares of the engine with a standard system at low and high speed (Fig. 3b). Shares of carbon monoxide are much smaller for the pressure cooling system, the largest difference occurs at low speed (2000 rev/min) and it amounts to $92 \mathrm{ppm}$, which means reduction in the shares of the component gases by nearly half. Above this speed, the shares of this compound are much smaller for the system pressure, although the reduction in the shares of this component is visible throughout the range of engine speed (Fig. 3c).

a)

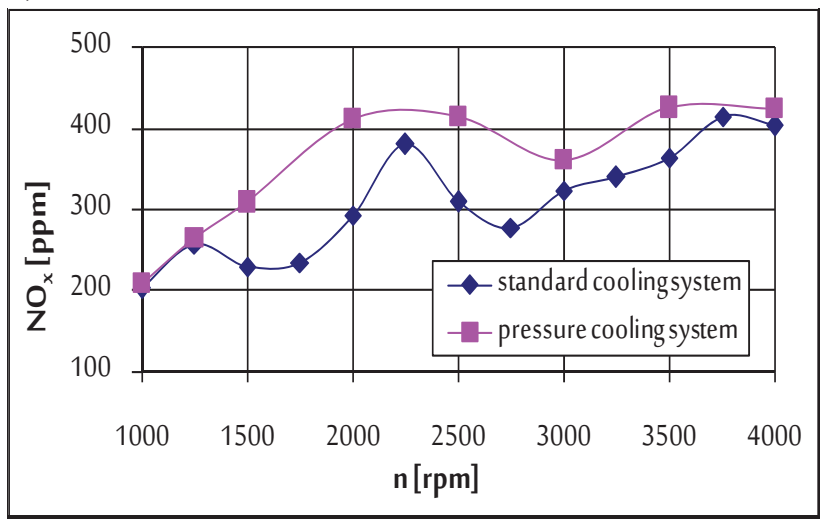

c)

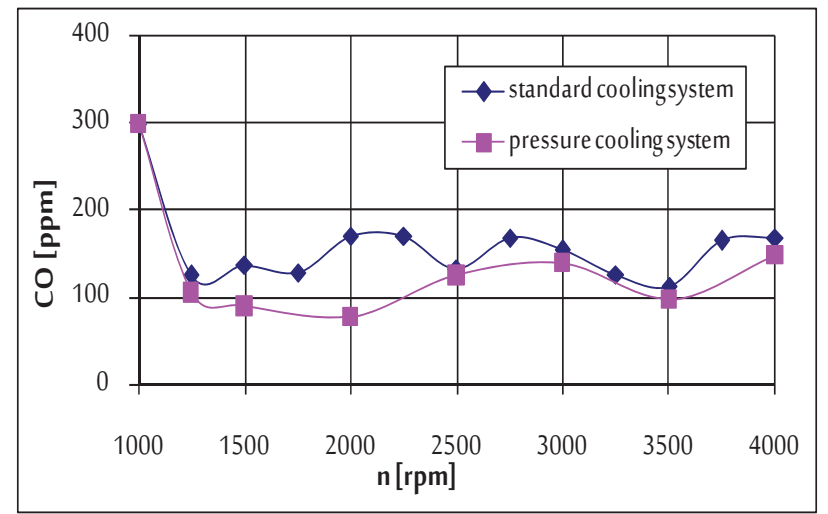

b)

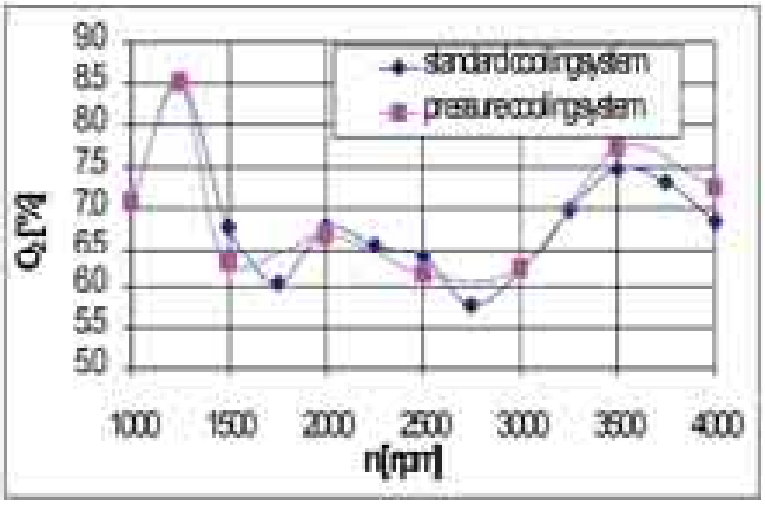

d)

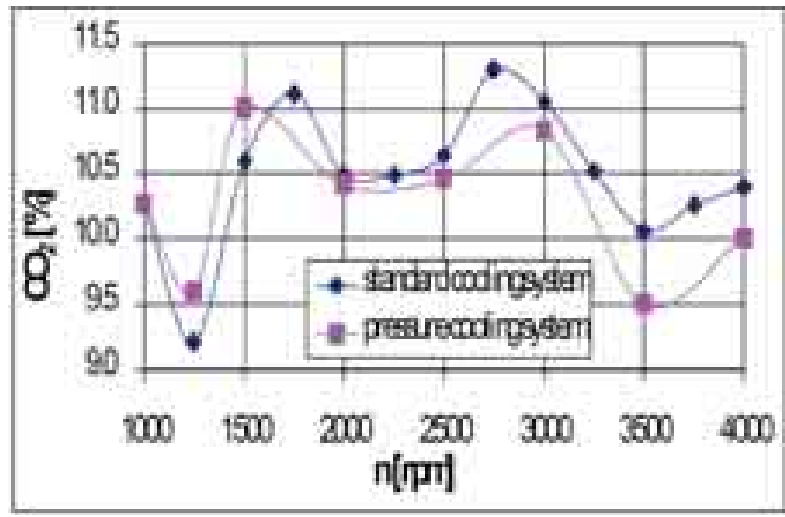

Fig. 3. The speed characteristics of the engine 4CT90 with standard and pressure cooling system: a-nitrogen oxide shares in the exhaust, b-oxygen shares in the exhaust, $c$ - carbon dioxide shares in the exhaust, $d$ - carbon monoxide shares in the exhaust

Shares of carbon dioxide for both systems are similar at low speed (Fig. 3d). Noticeable differences occur in the remaining range of the engine speed are roughly correlated with actual hourly fuel consumption and air. In the speed range, 1500-4000 rev/min. carbon dioxide shares are lower in the system pressure, and below this value are slightly larger. Smoke emission is much smaller for the pressure cooling system in the whole speed range with the largest difference amounting to $0.34 \mathrm{~m}^{-1}$ occurs at $2000 \mathrm{rev} / \mathrm{min}$ (Fig. 4a). It follows that the operating speed range in which the diesel engine usually works, there is less smoke. It is very beneficial in the aspect of environmental protection. 
a)

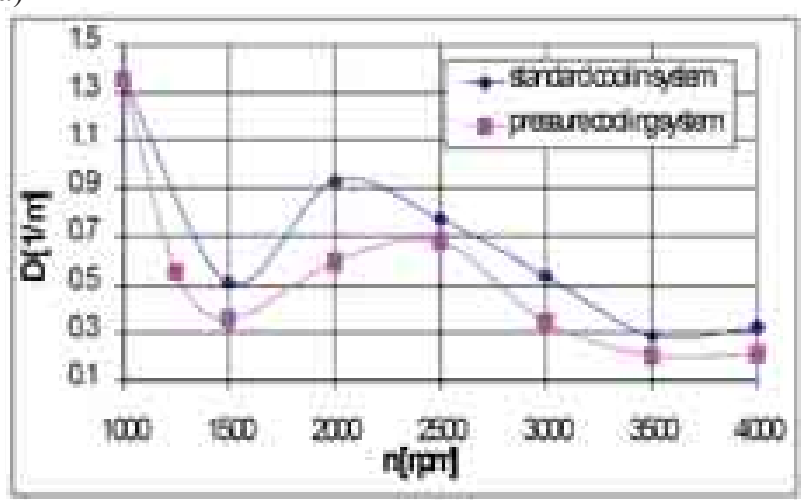

b)

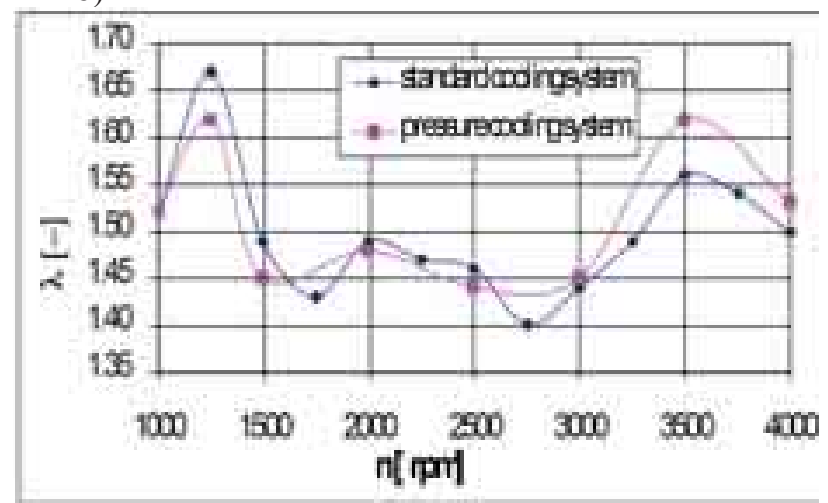

Fig. 4. The speed characteristics of the engine 4 CT90 with standard and pressure cooling system: $a$-smoke opacity, $b$ - air excess coefficient

Excess air ratio takes comparable values for pressure and standard cooling system in the speed range (Fig. 4b), although at high-speed growth rate is shown in comparison with the values measured for the standard system.

On the speed characteristics hydrocarbons shares was not presented, because at maximum engine load, shares of this compound in the exhaust gas are very low (of a few ppm) due to the effective operation of catalytic afterburner, with increased engine load (above 60 to $80 \mathrm{Nm}$ ), which on the engine load characteristics is seen.

\subsection{Impact of engine load on the exhaust gas composition}

In the whole range of load and engine speed emissions of nitrogen oxides in exhaust gases from an engine, running cooling system pressure is much higher (Fig. 5a). This is an increase from 20 to 120 $\mathrm{ppm}$, decaying differently as a function of engine speed and engine load. At low speed and high-growth engine temperature (coolant temperature rise of about 50 to $60^{\circ} \mathrm{C}$, the cylinder wall temperature around $50^{\circ} \mathrm{C}$ ), increase in the share of nitrogen oxides is nearly double (about 80 to $100 \mathrm{ppm}$ ). Similar increases occurred at 2000, although the relative increase is smaller and amounts to 50 to $30 \%$. At a speed above $2500 \mathrm{rev} / \mathrm{min}$ increase in the share of nitrogen oxides is 30 to $60 \mathrm{ppm}$ with the exception of speed of $3500 \mathrm{~min}$, where the increase is greatest (up to $120 \mathrm{ppm}$, which is about $30 \%$ ).

Shares of carbon monoxide and hydrocarbons are of similar nature of change. Regardless of engine speed range torque changes to about 100 to $120 \mathrm{Nm}$ can be noticed a marked reduction in shares of these compounds in the exhaust gas (Fig. 5b, c). The greatest reduction in shares of carbon oxides and hydrocarbons in the exhaust is at the lowest engine load. Reduction of carbon monoxide at a speed of $1500 \mathrm{rev} / \mathrm{min}$ and $30 \mathrm{Nm}$ load amounted $280 \mathrm{ppm}$ (relative change of about 60\%) and 12-ppm hydrocarbons (relative reduction 40\%).

When the load increased above $100 \mathrm{Nm}$ shares were comparable, with the turbine exhaust temperature in the load reached a value of about $300^{\circ} \mathrm{C}$ (Fig. $5 \mathrm{~d}$ ). Value is close to the temperature at which the catalytic conversion reaches its maximum (theoretical maximum conversion temperature is about $\left.280^{\circ} \mathrm{C}\right)$. At a speed of maximum torque $(2500 \mathrm{rev} / \mathrm{min})$ the reduction of carbon monoxide at a torque of $30 \mathrm{Nm}$ is approximately $130 \mathrm{ppm}$ (or approximately $30 \%$ ), hydrocarbons by $23 \mathrm{ppm}$ (or about 55\%), and the alignment shares were at a torque engine approximately $120 \mathrm{Nm}\left(330{ }^{\circ} \mathrm{C}\right.$ exhaust temperature). With a maximum speed of a change in the exhaust, gas components were lower and amounted to $35 \mathrm{ppm} \mathrm{CO}$ (reduction of about 15\%) and $\mathrm{CH} 15 \mathrm{ppm}$ (30\% reduction) at a torque of $90 \mathrm{Nm}$ compensation levels and a corresponding this torque - exhaust temperature $390^{\circ} \mathrm{C}$.

Coolant temperature rise very positive effect on the reduce smoke opacity in the whole range of load and engine speed (Fig. 5d). At low speed reduce the smoke opacity amounted about 0.15 $\mathrm{m}^{-1}$ (reduction of about $40 \%$ ), and at the largest torque up about $0.23 \mathrm{~m}^{-1}$ (reduction of about $40 \%$ ). 
At a speed $2000 \mathrm{rev} / \mathrm{min}$ reduce smoke opacity was lower by about $0.1 \mathrm{~m}^{-1}$ (less by about $30 \%$ ) of the average load of about $0.25 \mathrm{~m}^{-1}$ at the maximum load (reduction of about $30 \%$ ). Above the speed $2500 \mathrm{rev} / \mathrm{min}$ reduce smoke was much lower and amounted on average to about $0.02 \mathrm{~m}^{-1}$, which at the average opacity of $0.1 \mathrm{~m}^{-1}$ gives a reduction of about $10 \%$, but at a very low level of opacity. Noticeable contrast is a significant reduction in smoke with pressure cooling system at the maximum load torque at comparable engine, up to about 20 to $30 \%$.

Shares of oxygen and carbon dioxide are equivalent to the course (Fig. 6a, b) which means that the increase of oxygen in the exhaust gas shares corresponds to the proportional reduction in the shares of carbon dioxide. On average, the absolute values of oxygen are higher by about $0.5-1 \%$ and the same is comparatively less carbon dioxide in the exhaust.

a)

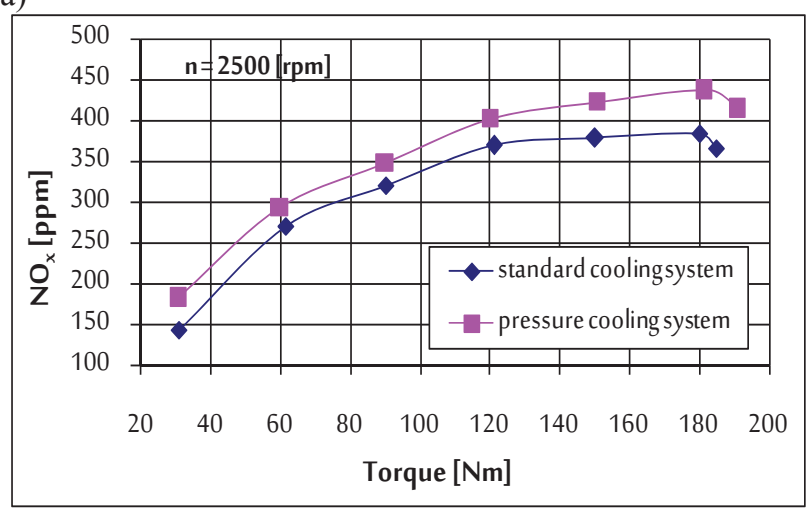

c)

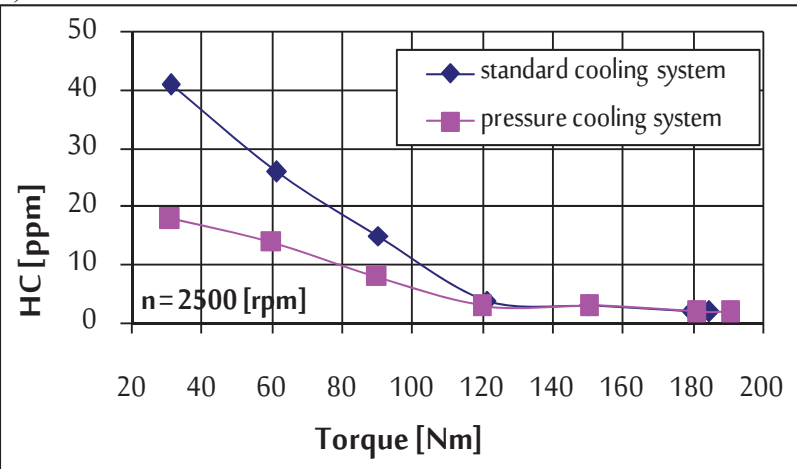

b)

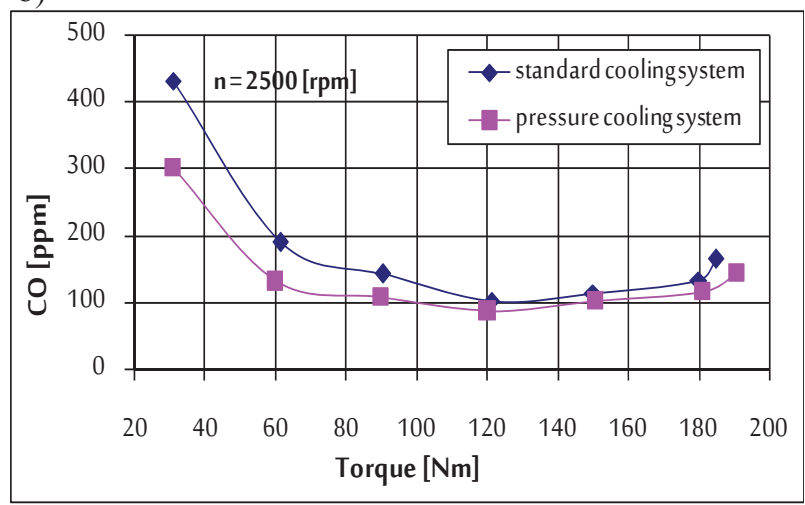

d)

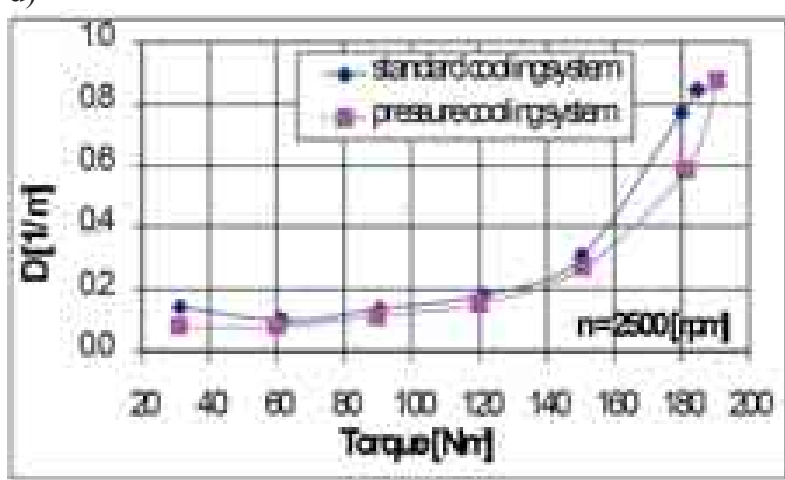

Fig. 5. The load characteristics of the engine $4 C T 90$ with standard and pressure cooling system at $n=2500 \mathrm{rev} / \mathrm{min}$ : $a$-nitrogen oxide shares in the exhaust, $b$-carbon monoxide shares in the exhaust, $c$ - hydrocarbons shares in the exhaust, $d$-smoke opacity

a)

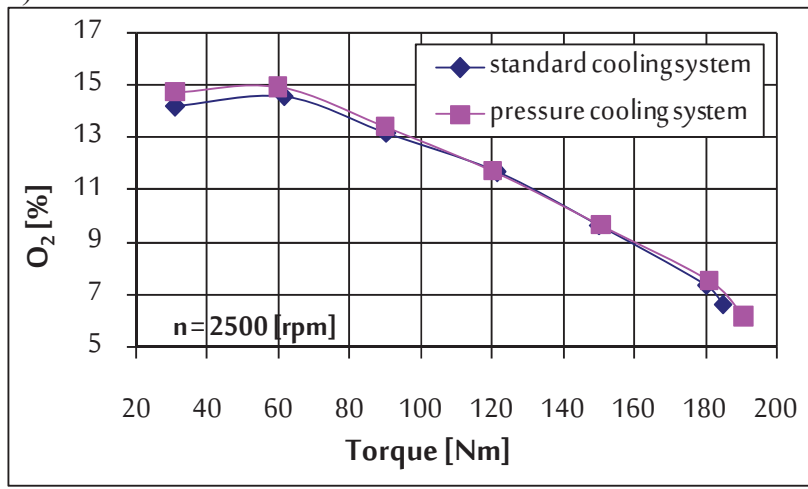

b)

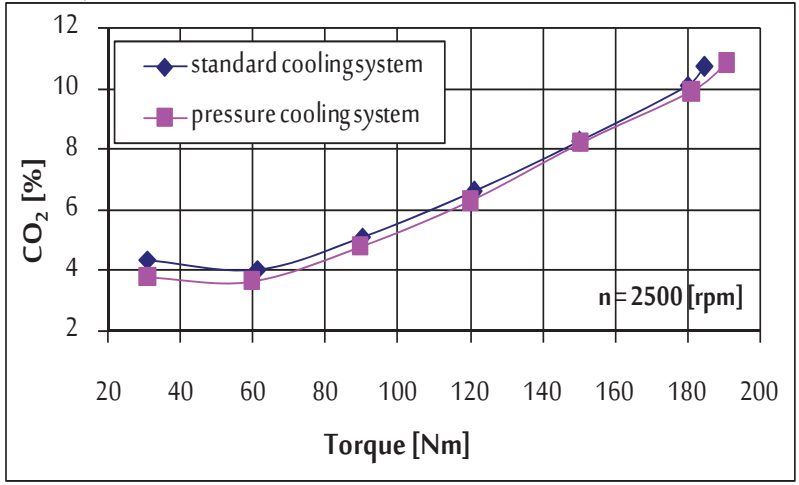

Fig. 6. The load characteristics of the engine $4 C T 90$ with standard and pressure cooling system at $n=2500 \mathrm{rev} / \mathrm{min}$ : $a$-oxygen shares in the exhaust, $b$ - carbon dioxide shares in the exhaust 
The load characteristics show that the use of pressure cooling system reduces the share of carbon monoxide, hydrocarbons and carbon dioxide in the exhaust smoke opacity also has a smaller value. The shares of nitrogen oxides in exhaust gases are higher for pressure cooling system, therefore, needs an additional application of reducing nitrogen oxides. These reactors were not on the bench, equipped with only the oxidation reactors.

\section{Conclusions}

Research carried out at the test bench showed that the charge air cooler used as a water cooler with increased pressure, is characterized by very low thermal capacity and therefore installed in the system heat exchanger shell and tube. The heat was discharged from the exchanger by flowing water from the mains supply. This allowed for testing cooling system at a higher pressure and temperature.

Pressure system is characterized by a higher temperature load in relation to the standard system, which helped to improve fuel mixing and burning it. The temperature influence on the growth of economy and engine torque. The economy of engine improved by an average of about $7 \%$.

The increased engine temperature decreases by about $30-50 \%$ of carbon monoxide and hydrocarbons at low engine load. These changes are significant, especially at low engine speed, because in this area shares the exhaust components are the biggest, reaching several hundred ppm, but it is an area of the engine where the exhaust temperature does not provide the high degree of catalytic conversion. Moreover, at these loads, the engine operates most often in urban conditions.

The shares of nitrogen oxides in exhaust gases are much higher for the pressure cooling system in the whole speed range and this is an increase of 60 to $100 \mathrm{ppm}$, in comparison to the standard cooling system. Therefore, pressure-cooling system requires an additional reducing nitrogen oxides. These reactors were not on the bench, equipped with only the oxidation reactors.

Smoke opacity is lower for the pressure cooling system in the whole speed range with the largest difference amounting to $0.34 \mathrm{~m}-1$ occurs at $2000 \mathrm{rev} / \mathrm{min}$.

The exhaust gas temperature before and after the turbine was significantly higher in the whole range of engine speed and load. The temperature of the coolant entering the radiator was higher for the engine with a pressure system and reached a value of about $120^{\circ} \mathrm{C}$ at a speed of $2500-4000$ $\mathrm{rev} / \mathrm{min}$ in the whole range load. While the temperature of the fluid coming from the radiator and into the engine had a similar course in each case. The greatest differences of up to $40^{\circ} \mathrm{C}$ took place at lower speeds.

\section{References}

[1] Bernhardt, M., Dobrzyński, S., Loth, E., Silniki samochodowe, WKiÆ, Warszawa 1988.

[2] Bielaczyc, P., Merkisz, J., Pielucha, J., Stan cieplny silnika spalinowego a emisja zwiąków szkodliwych, Wydawnictwo Politechniki Poznańskiej, Poznań 2001.

[3] Cortona, E., Onder, Ch. H., Engine thermal management with electric cooling pump, SAE Technical Paper Series, 2000-01-0965.

[4] Kneba, Z., Kompleksowy model nowej generacji uktadu chłodzenia silnika spalinowego, Silniki spalinowe, SC1, pp. 160-169, Bielsko-Biała 2007.

[5] Krakowski, R., Walentynowicz, J., Wpływ podwyższonej temperatury płynu chłodzacego na działanie układu chłodzenia tłokowego silnika spalinowego, Światowy Zjazd Inżynierów Polskich, Warszawa 2010.

[6] Luft, S., Podstawy budowy silników, WKŁ, Warszawa 2006. 
[7] Merkisz, J., Wpływ motoryzacji na skażenie środowiska naturalnego, Wydawnictwo Politechniki, Poznań 1994.

[8] Ogrodzki, A., Chłodzenie trakcyjnych silników spalinowych, WKŁ, Warszawa 1974.

[9] Principles of engine cooling systems, components and maintenance, SAE HS-40.

[10] Wajand, J. A., Wajand, J. T., Ttokowe silniki spalinowe średnio - i szybkoobrotowe, WNT, Warszawa 1993.

[11] Walentynowicz, J., Influence of the Cooling Liquid Temperature on the Piston Combustion Engine Parameters, Journal of KONES, 2009. 